\title{
Improving access to health care for malaria in Africa: a review of literature on what attracts patients
}

\author{
James Kizito ${ }^{1 *}$, Miriam Kayendeke ${ }^{1}$, Christine Nabirye ${ }^{1}$, Sarah G Staedke ${ }^{1,2}$ and Clare IR Chandler ${ }^{3}$
}

\begin{abstract}
Background: Increasing access to health care services is considered central to improving the health of populations. Existing reviews to understand factors affecting access to health care have focused on attributes of patients and their communities that act as 'barriers' to access, such as education level, financial and cultural factors. This review addresses the need to learn about provider characteristics that encourage patients to attend their health services.

Methods: This literature review aims to describe research that has identified characteristics that clients are looking for in the providers they approach for their health care needs, specifically for malaria in Africa. Keywords of 'malaria' and 'treatment seek*' or 'health seek*' and 'Africa' were searched for in the following databases: Web of Science, IBSS and Medline. Reviews of each paper were undertaken by two members of the team. Factors attracting patients according to each paper were listed and the strength of evidence was assessed by evaluating the methods used and the richness of descriptions of findings.

Results: A total of 97 papers fulfilled the inclusion criteria and were included in the review. The review of these papers identified several characteristics that were reported to attract patients to providers of all types, including lower cost of services, close proximity to patients, positive manner of providers, medicines that patients believe will cure them, and timeliness of services. Additional categories of factors were noted to attract patients to either higher or lower-level providers. The strength of evidence reviewed varied, with limitations observed in the use of methods utilizing predefined questions and the uncritical use of concepts such as 'quality', 'costs' and 'access'. Although most papers (90\%) were published since the year 2000, most categories of attributes had been described in earlier papers.

Conclusion: This paper argues that improving access to services requires attention to factors that will attract patients, and recommends that public services are improved in the specific aspects identified in this review. It also argues that research into access should expand its lens to consider provider characteristics more broadly, especially using methods that enable open responses. Access must be reconceptualized beyond the notion of barriers to consider attributes of attraction if patients are to receive quality care quickly.
\end{abstract}

Keywords: Access, Treatment seeking, Malaria, Attracting factors, Health care providers

\section{Background}

Increasing access to health care services is considered central to improving the health of populations. Prompt access to malaria diagnosis and treatment is a key component of the Roll Back Malaria Partnership's Global Malaria Action Plan to reduce deaths attributable to

\footnotetext{
* Correspondence: naremu2002@yahoo.co.uk

'Uganda Malaria Surveillance Project, Infectious Diseases Research

Collaboration, Kampala, Uganda

Full list of author information is available at the end of the article
}

malaria to near-zero by 2015 [1]. Much research has been conducted to understand how to improve access to services in low-resource settings, including for malaria care, and frameworks for this are myriad [2-6]. Two key features of access-oriented studies are their focus on barriers to access, and their focus on attributes of individuals and communities. Findings of such studies are often that financial, educational and cultural issues need to be addressed, with conclusions drawn that surmounting such barriers will enable universal uptake of services.

\section{Biomed Central}


In the case of access to health care for malaria, surveys have shown that treatment and even diagnostics are often procured outside of public sector services. Febrile patients are treated in many arenas, from the home, to drug shops, to private clinics and public health facilities. The majority of treatment for malaria is sought outside of the home and outside of the public sector in Africa [7]. This begs the question that services designed from the supply side, as in the case of public services, may not meet demand. In spite of the huge amount of research into malaria treatmentseeking, gaps remain in our understanding of provider characteristics [8]. The focus on individual and community 'barriers' to access of public health services [9] overshadows important lessons that could be learned from decisions to access other health care services.

This paper reviews the literature to understand treatment-seeking beyond barriers to access, focusing on research that has described what clients are looking for in the providers they approach for their health care needs. Thus, it moves away from individual and household decision-making, and individual characteristics of population groups, to look at the characteristics of providers that attract clients. The review aims to enable public health services to learn what they are perceived to do well, and what other competitors in the health services marketplace are also doing well to attract clients.

\section{Methods}

The keywords 'malaria' and 'treatment seek" or 'health seek" and 'Africa' were searched for in the following databases: Web of Science, IBSS and Medline. The citation lists of the papers meeting eligibility criteria were then read in order to identify further papers, books, reports or other grey literature considered potentially relevant to the topic from the title. Abstracts were reviewed for each paper considered potentially relevant from its title, and those that remained potentially relevant were then retrieved and reviewed in full. The eligibility criteria were as follows:

Inclusion criteria

- About treatment-seeking for illnesses including malaria in Africa

- Describes provider characteristics found to positively affect patient access or choice to use that provider

- Presents analysis of primary empirical data

- Published any date before April 2011

- Does not meet exclusion criteria

Exclusion criteria

- Papers only focused on self-treatment
- Papers only focused on patient/household characteristics associated with provider use

- Data collected outside Africa

- Review or opinion papers without new data presented

- Papers in languages other than English

- Papers for which the full text could not be found, including conference presentations

- PhD theses

Reviews of each paper were undertaken by two members of the team. After reading the whole paper, reviewers extracted specific information into an Excel spreadsheet, detailing the location, study population and methods of the study as well as rationales given for preferred treatment sources in that population. The different rationales given across the different studies were then reviewed and a list of categories of 'attracting factors' was generated by grouping thematically all provider factors reported to have had a positive effect on decisions to seek treatment at that provider. A matrix was then constructed, such that papers could be entered according to the factor presented and the type of provider this was relevant to, where specified. For each paper, strength of evidence was assessed by evaluating (1) the methods used that contributed to the findings included in the review matrix, with open-ended methods considered more useful for eliciting relevant information than closed-ended methods, and (2) the richness of descriptions of findings relevant to the review's objective.

The papers and categories of attracting factors emerging were also reviewed by publication date, to assess any changes in factors reported over time. Papers were grouped by decade and the matrix of attracting factors and provider types was reviewed for contributions from papers from each decade.

\section{Results}

\section{Papers identified and included}

After screening titles, the sources searched provided the following number of potentially relevant papers/books (hereafter referred to as 'papers'):

- Web of Science: 157

- IBSS: 20

- Medline: 69

- Reference lists of retrieved papers: 82

After removing duplicates, a total of 267 abstracts were reviewed. Neither abstract nor full text could be obtained for four references. A total of 114 references were excluded after reading the abstract. All remaining papers were read in full, except for five, which could not be obtained. Of these remaining 145 papers, 48 were 
excluded, leaving 97 papers that fulfilled the inclusion criteria.

The articles were published between the years 1986 and 2011, with a median year of publication of 2006, showing a rapid increase in studies published in the past few years.

\section{Populations of included studies}

The studies included in the review were carried out in 14 different countries, with the majority conducted in East Africa: Tanzania $(\mathrm{n}=26)$, Uganda $(\mathrm{n}=15)$ and Kenya $(\mathrm{n}=8)$ followed by West Africa, particularly in Nigeria $(\mathrm{n}=18)$ and Ghana (7). Studies included from Francophone West Africa were few, in Burkina Faso $(n=3)$, Gambia $(\mathrm{n}=2)$ and Gabon $(\mathrm{n}=1)$. Between one and three papers provided data from each Malawi, Zambia, Mozambique and South Africa. Two North African countries were represented: Ethiopia $(\mathrm{n}=7)$ and Sudan $(\mathrm{n}=2)$. There were no studies eligible for inclusion from Central African countries.

Of the 97 papers included in this review, almost half, $48.5 \%(n=47)$ focused on health-seeking for children, $46.4 \%(\mathrm{n}=45)$ focused on health-seeking for both children and adults, and $4.7 \%(\mathrm{n}=5)$ had a sole focus on adults. In all, $73.2 \%(\mathrm{n}=71)$ took place amongst rural populations, $20.6 \%(\mathrm{n}=20)$ were conducted in mixed rural/urban settings, and $6.2 \%(n=6)$ were limited to urban areas.

\section{Methodologies of included studies}

Methods used by studies to obtain information that is included in this review were qualitative and quantitative, and often mixed. Most commonly, fieldwork included in-depth or 'key informant' interviews $(\mathrm{n}=45)$, survey questionnaires $(\mathrm{n}=44)$ and focus group discussions (in 43 studies). Many also described using 'semi-structured interviews' $(\mathrm{n}=18)$, although it is possible these interviews varied in their level of depth as description of questions was often vague. Ethnography or participant observation was carried out in 13 studies. Narratives, case histories and informal conversations were grouped under the category of in-depth/key informant interviews.

In all, $70 \%(n=68)$ papers were classified as contributing 'stronger evidence' to the review, defined by the methods used and richness of descriptions of the findings. All of these papers had used methods that included on openended questioning, enabling respondent to give responses beyond pre-defined a priori categories $(70 \%, \mathrm{n}=68)$. A total of $31 \%(n=30)$ papers were also classified as providing rich descriptions of findings relevant to the review's objective.

\section{Factors reported to attract patients to providers}

The findings of the review, shown as a matrix of attracting factors by provider type, can be seen in Table 1, 2,
$3,4,5$. The papers identified a number of factors positively affecting patient choice to attend different providers, 'attracting factors'. Higher-level providers included hospitals (reported in 27 publications), public health centres or dispensaries $(\mathrm{n}=33)$ and private clinics or health centres $(n=23)$. Lower-level providers included pharmacies and drug shops $(\mathrm{n}=33)$, traditional healers and local herbalists $(\mathrm{n}=31)$ and community health workers $(n=11)$. Some factors attracting patients were reported to be important across the different provider types, whilst others were specific to different types of provider, often clustered into 'high level' and 'low level' providers.

\section{Factors important across all provider types}

Interestingly, many of the factors reported to attract patients to providers were important across the different provider types. These included low cost of services, proximity of treatment source to the patient, a belief that the provider or their medicines could cure the illness and positive manner of the provider.

Low cost of services encapsulated reports of preferences for, or improved access to, services that were low in absolute cost or for which patients could negotiate over price or quantities or receive on credit. The former attributes, especially free services, were associated with public facilities or local herbs whilst the latter attributes were most commonly identified with drug shops.

Proximity or easy access to the health care providers was also a key factor reported, reflecting preferences for providers located nearby or in a location to where transport was easy to secure and afford. Provider timeliness of services included convenient opening hours and short waiting times. Longer opening hours of drug shops appealed to patients requiring attention at night or at weekends.

Provider supplies that were reported to attract patients were most commonly the availability of drugs, although specific facilities were also attractive, particularly having a laboratory, a ward, and good infrastructure, equipment like microscopes, injections and drips, most commonly reported as attracting factors at public health facilities. These also related to the desire for specialist services, including investigations, transfusions, surgery and admissions at higher-level facilities, whilst first aid was cited as an attracting factor at lower-level providers, such as drug shops and community health workers.

Papers also reported that patients were attracted to providers where they believed the treatment or medicines would cure their illness. For example, many reported recognition of traditional healers as the best to treat cases of convulsions or illnesses with spiritual causes. Patients were reported to attend biomedical health facilities because they believed that these facilities 
Table 1 Matrix of factors reported by papers to attract care seekers to different provider types: Cost of services

\begin{tabular}{|c|c|c|c|c|c|c|c|}
\hline Provider type & $\begin{array}{l}\text { Community } \\
\text { health workers } \\
(n=4)\end{array}$ & $\begin{array}{l}\text { Drug shop/pharmacy } \\
(n=19)\end{array}$ & $\begin{array}{l}\text { Traditional } \\
\text { healer } \\
(n=4)\end{array}$ & $\begin{array}{l}\text { Private health } \\
\text { centre/facility } \\
(n=3)\end{array}$ & $\begin{array}{l}\text { Public health } \\
\text { centre/facility } \\
(n=10)\end{array}$ & $\begin{array}{l}\text { Hospital } \\
(n=3)\end{array}$ & $\begin{array}{l}\text { Provider type not specified } \\
(n=13)\end{array}$ \\
\hline \multirow[t]{6}{*}{$\begin{array}{l}\text { Cost of services at the } \\
\text { provider (including } \\
\text { consultation, treatment, } \\
\text { supplies) } \\
(n=44)\end{array}$} & $\begin{array}{l}\text { 'Cheap' } \\
\text { Ethiopia[10], } \\
\text { Uganda[11] } \\
\frac{\text { (traditional birth }}{\text { attendants) }}\end{array}$ & $\begin{array}{l}\text { 'Cheap' } \\
\text { Kenya[14], Tanzania[15], Uganda [16-18] } \\
\text { Nigeria [19], [20] Ghana [21], Ethiopia } \\
\text { [22], Tanzania[23], Malawi[24], Nigeria } \\
{[25,26]}\end{array}$ & $\begin{array}{l}\text { 'Cheap'Burkina } \\
\text { Faso[33] }\end{array}$ & $\begin{array}{l}\text { 'Cheap' Uganda } \\
\text { [16] }\end{array}$ & $\begin{array}{l}\text { Free services } \\
\text { Malawi [36]South } \\
\text { Africa [37] Kenya } \\
\text { [38], Tanzania } \\
{[31]} \\
\text { Ethiopia [39] }\end{array}$ & $\begin{array}{l}\text { 'Free services' Kenya } \\
\text { [35] }\end{array}$ & $\begin{array}{l}\text { 'Free or cheap drugs' } \\
\text { Uganda }[45,46] \text { Tanzania }[47\end{array}$ \\
\hline & $\begin{array}{l}\text { 'No charge' } \\
\text { Uganda }[12,13]\end{array}$ & $\begin{array}{l}\text { 'Affordable' drug vendors } \\
\text { Nigeria[27,28]Ghana[29] }\end{array}$ & $\begin{array}{l}\text { 'For those who } \\
\text { find it difficult } \\
\text { to pay' } \\
\text { Tanzania [23], } \\
\text { Uganda[32] }\end{array}$ & $\begin{array}{l}\text { 'Reduced cost' } \\
\text { Kenya[35] }\end{array}$ & $\begin{array}{l}\text { 'Free if unable to } \\
\text { pay' Tanzania } \\
{[34]}\end{array}$ & $\begin{array}{l}\text { 'Low cost' Uganda } \\
\text { [41] }\end{array}$ & $\begin{array}{l}\text { 'Inexpensive services' } \\
\text { Nigeria [48] Ghana [21], } \\
\text { Nigeria[20], Kenya[14], } \\
{[38,49,50], \text { Mozambique[51] }} \\
\text { Ethiopia [52] }\end{array}$ \\
\hline & & 'Charge less than others' Kenya [30] & $\begin{array}{l}\text { 'Flexible in } \\
\text { payment' } \\
\text { Tanzania[34] }\end{array}$ & $\begin{array}{l}\text { 'Can get } \\
\text { treatment on } \\
\text { credit' Uganda } \\
\text { [16], Nigeria [28] }\end{array}$ & $\frac{\text { 'Free if Under 5yr }}{\text { olds'Gambia }[40]}$ & $\begin{array}{l}\text { 'Economical for } \\
\text { finding out the } \\
\text { cause of an illness' } \\
\text { Tanzania[44] }\end{array}$ & $\begin{array}{l}\text { Affordable } \\
\text { Tanzania[53] }\end{array}$ \\
\hline & & $\begin{array}{l}\text { 'Can get treatment on credit' Uganda } \\
{[16] \text {, Tanzania [31], Nigeria }[27,19,26]}\end{array}$ & & $\begin{array}{l}\text { 'Pay according to } \\
\text { the treatment } \\
\text { you get' Kenya } \\
\text { [35] }\end{array}$ & $\begin{array}{l}\text { 'Low cost' } \\
\text { Mozambique [37] } \\
\frac{\text { Uganda[41], }}{\underline{\text { Sudan[ }[42]}}\end{array}$ & & $\begin{array}{l}\text { 'Flexibility in mode of } \\
\text { payment' } \\
\text { Kenya[14] }\end{array}$ \\
\hline & & 'Option of bargaining' Nigeria[20] & & $\begin{array}{l}\text { 'Prices are } \\
\text { negotiable' } \\
\text { Kenya[35] }\end{array}$ & $\begin{array}{l}\text { 'Can get } \\
\text { treatment on } \\
\text { credit' Tanzania } \\
{[31]}\end{array}$ & & \\
\hline & & $\begin{array}{l}\text { 'Give medicine according to the money } \\
\text { you can afford' Uganda[32] }\end{array}$ & & & $\begin{array}{l}\text { 'Covered by } \\
\text { insurance' Ghana } \\
{[43]}\end{array}$ & & \\
\hline
\end{tabular}

Note: Papers providing a rich description of attracting factors are marked in bold; findings from methods involving open-ended questions are underlined. 
Table 2 Matrix of factors reported by papers to attract care seekers to different provider types: Proximity and timeliness of services

$(n=7)$

Drug shop/ $(n=23)$

Proximity or easy

access/lower cost of

'Close by' Uganda [54]
Nigeria \& Ghana \& Uganda
$\frac{\text { \& Kenya[55], Ethiopia[10,13], }}{\text { Nigeria }[56,57]}$

'Close by' Uganda [54,32,16,18], 'Close by'

$\begin{array}{ll}\text { Ethiopia [22] Ghana[29], Kenya } & \text { Uganda } \\ \text { [14], Nigeria }[28,26,58,57] & \text { Nigeria }\end{array}$

Malawi $[59,24]$

Nigeria

'Easy access' Uganda[17]

(traditional birth attendants)

'Less travel' Ghana [43], 'Easy access'

Tanzania[15] Malawi [36] Uganda[32]

'Save on transport cost' Nigeria

[27] Ghana [21] Kenya [30] transport $(n=42)$

Public health centre/facility Hospital

$(n=10)$

$(n=2)$

Provider type not specified

health

centre/

facility

'Close by'

Nigeria [28]

Ghana [21]

'Close by' Health centre

'Close by'

Zambia[60], Uganda[12,16], Nigeria [58]

Nigeria $[62]$

Nigeria [58]

Burkina Faso

'Close by'Ethiopia [52]Sudan

[64], Nigeria [20,48], Ghana

[21] Tanzania [47,4] $\underline{\text { Uganda }}$

[46], Kenya [38]

'Easy access' Uganda[41] Kenya[63]

'Easy access' Mozambique[51] Tanzania[53], Kenya [49]

Save on transport cost' Kenya [38], Mozambique[51], Ghana [21]

\begin{tabular}{lll}
\hline $\begin{array}{l}\text { Provider timeliness of } \\
\text { services (opening } \\
\text { hours and waiting }\end{array}$ & $\begin{array}{l}\text { 'Short waiting time' Nigeria } \\
\text { times) }(\boldsymbol{n}=\mathbf{2 1})\end{array}$ & $\begin{array}{l}\text { 'Available 24 hrs' Kenya[14], } \\
\text { Nigeria[19] }\end{array}$ \\
& \\
& 'Longer opening hours' \\
& $\underline{\text { Nigeria[20], Uganda[18] }}$ \\
& 'Convenient treatment times' \\
& Ghana [43] \\
& \\
& 'Short waiting time' Ghana \\
& {$[21,43]$, Ethiopia [22], Tanzania } \\
& {$[31]$ Malawi [36], Uganda[18] } \\
& 'Provide fast services' \\
& $\underline{\text { Uganda[18] }}$
\end{tabular}

'Available at 'Operate for 'Fast services for malaria

convenient longer hours' cases' Nigeria [66]

hours' Ghana[65]

Tanzania [34]

'Short 'Short waiting time' Ethiopia

Kenya[14],

'Provide

faster

services'

Kenya [35] waiting time' [39]

'Short waiting time' Ethiopia

[52], Ghana [21], Kenya [38,49]

Uganda[46] Nigeria [48]

Note: Papers providing a rich description of attracting factors are marked in bold; findings from methods involving open-ended questions are underlined. 
Table 3 Matrix of factors reported by papers to attract care seekers to different provider types: Belief in provider and ability to choose drugs

$\begin{array}{cllllll}\text { Provider type } \begin{array}{l}\text { Community } \\ \text { health workers } \\ (n=3)\end{array} & \begin{array}{l}\text { Drug shop/ } \\ \text { pharmacy } \\ (n=7)\end{array} & \begin{array}{l}\text { Traditional healer } \\ (n=27)\end{array} & & \begin{array}{l}\text { Private health } \\ \text { centre/facility } \\ (n=10)\end{array} & \begin{array}{l}\text { Public health centre/facility } \\ (n=11)\end{array} & \begin{array}{l}\text { Hospital } \\ (n=8)\end{array} \\ \text { type not } \\ \text { specified } \\ (n=8)\end{array}$

Attracting factor

Belief the provider

and/or their

treatments can cure

the illness $(n=51)$

'Their drug

Tanzania $[34,67,44,68,69] \cup$ ganda[70],

Ghana $[82,21]$

Ethiopia [87]Zambia[60], Nigeria

Gambia [90], Nigeria Tanzania

$(n=8)$

Nigeria \& Ghana

Uganda[17,

Malawi $[59,24]$ Nigeria $[20,71,19,26]$ Kenya

[35], Ghana[72], Uganda[32], Burkina Faso

[61], Gabon[73]

Tanzania[83,84]

ganda $[11,17]$

[26,66,86], Burkina Faso[61], Gabon

$[85,20,86]$ Tanzania

$\frac{\text { Tanzania }}{[68,67,91]}$

Kenya[55],

Nigeria $[57,56]$

Kenya $[35,63]$,

Uganda [89]

[44,76]Burkina Faso $[61]$

$\frac{\text { Uganda }}{[17,45]}$

Burkina

Faso [92],

Ghana [21]

Ethiopia

[52]

'Effective for convulsions associated to

Treatment is comprehensive'

witchcraft' Zambia[60]

Treatment
Kenya[14]

'Effective for convulsions' Nigeria $[20,74]$

Tanzania [75,76]Ethiopia[77]

'Effective for illnesses with natural or

spiritual cause'

Zambia[78], Tanzania [79,80] Nigeria[74]

Ghana [21]

'Effective for illness unusual in

presentation' Nigeria [81],

\begin{tabular}{|c|c|}
\hline \multirow[t]{2}{*}{$\begin{array}{l}\text { Provider allows the } \\
\text { patient to choose } \\
\text { what they want ( } n= \\
\text { 2) }\end{array}$} & $\begin{array}{l}\text { 'Can buy any } \\
\text { quantity of } \\
\text { drugs you want } \\
\text { Nigeria[26] }\end{array}$ \\
\hline & $\begin{array}{l}\text { 'Can make a } \\
\text { choice on the } \\
\text { kind of drug' } \\
\text { Nigeria [58] }\end{array}$ \\
\hline
\end{tabular}

Note: Papers providing a rich description of attracting factors are marked in bold; findings from methods involving open-ended questions are underlined. 
Table 4 Matrix of factors reported by papers to attract care seekers to different provider types: Staff and service characteristics

\begin{tabular}{|c|c|c|c|c|c|c|c|}
\hline Provider type & $\begin{array}{l}\text { Community } \\
\text { health workers } \\
(n=3)\end{array}$ & $\begin{array}{l}\text { Drug shop/pharmacy } \\
(n=7)\end{array}$ & $\begin{array}{l}\text { Traditional healer } \\
(n=2)\end{array}$ & $\begin{array}{l}\text { Private health centre/ } \\
\text { facility } \\
(n=7)\end{array}$ & $\begin{array}{l}\text { Public health } \\
\text { centre/facility } \\
(n=8)\end{array}$ & $\begin{array}{l}\text { Hospital } \\
(n=7)\end{array}$ & $\begin{array}{l}\text { Provider type not } \\
\text { specified } \\
(n=3)\end{array}$ \\
\hline \multicolumn{8}{|l|}{ Attracting factor } \\
\hline \multirow[t]{2}{*}{$\begin{array}{l}\text { Positive manner of } \\
\text { staff } \\
(n=10)\end{array}$} & $\begin{array}{l}\text { 'Show care to } \\
\text { patients' } \\
\text { Uganda[12] } \\
\text { Ethiopia[13] }\end{array}$ & $\begin{array}{l}\text { 'Show care to patients' } \\
\text { Uganda [18] }\end{array}$ & $\begin{array}{l}\text { 'Show care to patients' } \\
\text { Tanzania [34], } \\
\text { Uganda[32] }\end{array}$ & $\begin{array}{l}\text { 'Show care to patients' } \\
\text { Uganda[70], }\end{array}$ & $\begin{array}{l}\text { 'Polite' Nigeria } \\
\text { [62] }\end{array}$ & $\begin{array}{l}\text { 'Friendly attitude' } \\
\underline{\text { Zambia[93] }}\end{array}$ & $\begin{array}{l}\text { 'Build relationships } \\
\text { with patients' Kenya } \\
\text { [49] }\end{array}$ \\
\hline & $\begin{array}{l}\text { 'Good } \\
\text { communication' } \\
\text { Ethiopia[13] }\end{array}$ & $\begin{array}{l}\text { 'Good communication' } \\
\underline{\text { Uganda[18] }}\end{array}$ & & $\frac{\text { 'Friendly attitude' }}{\text { Nigeria [28] }}$ & & $\begin{array}{l}\text { 'Staff are dedicated' } \\
\underline{\text { Zambia[93] }}\end{array}$ & \\
\hline \multirow{2}{*}{$\begin{array}{l}\text { Qualification and } \\
\text { experience of } \\
\text { provider } \\
(n=6)\end{array}$} & & & & & $\begin{array}{l}\text { 'For trained staff' } \\
\text { Nigeria [66] } \\
\text { Uganda [16] }\end{array}$ & $\begin{array}{l}\text { 'For skilled staff' } \\
\text { Tanzania [47] }\end{array}$ & $\begin{array}{l}\text { 'For trained staff' } \\
\text { Nigeria[20] } \\
\underline{\text { Zambia }}[60]\end{array}$ \\
\hline & & & & & $\begin{array}{l}\text { 'For experienced } \\
\text { staff' Tanzania } \\
\text { [34], } \\
\text { Uganda [16] }\end{array}$ & & $\begin{array}{l}\text { 'Availability of a } \\
\text { Doctor' Nigeria[20] }\end{array}$ \\
\hline \multirow[t]{6}{*}{$\begin{array}{l}\text { Specialist services } \\
\text { offered by provider } \\
(n=17)\end{array}$} & $\begin{array}{l}\text { 'For Advice' } \\
\text { Ghana[72] }\end{array}$ & $\begin{array}{l}\text { 'For Advice' Ghana[72], } \\
\underline{\text { Uganda[32] }}\end{array}$ & $\begin{array}{l}\text { 'Conduct home visits and } \\
\text { provide follow-up care' } \\
\text { Uganda[32] }\end{array}$ & $\begin{array}{l}\text { 'For advice' } \\
\text { Tanzania [96] }\end{array}$ & $\begin{array}{l}\text { 'For First Aid' } \\
\text { Ethiopia[95], }\end{array}$ & 'For Advice' Kenya[100] & \\
\hline & & $\begin{array}{l}\text { 'For first Aid' Uganda [16], } \\
\text { Ghana [94], Ethiopia[95], } \\
\text { Malawi[24] }\end{array}$ & & $\begin{array}{l}\text { 'For Advice and further } \\
\text { examination' Tanzania } \\
\text { [97] }\end{array}$ & $\begin{array}{l}\text { 'For injections' } \\
\text { Tanzania [34] }\end{array}$ & $\begin{array}{l}\text { 'For testing /diagnosis' } \\
\frac{\text { Tanzania[98]Nigeria }}{[26]}\end{array}$ & \\
\hline & & & & $\begin{array}{l}\text { 'For first Aid' Uganda } \\
\text { [16], Ethiopia[95] }\end{array}$ & $\frac{\frac{\text { 'For blood }}{\text { transfusion' }}}{\text { Tanzania[23] }}$ & $\begin{array}{l}\text { 'For thorough } \\
\text { examination' Zambia } \\
\text { [93] }\end{array}$ & \\
\hline & & & & $\begin{array}{l}\text { 'For testing' Tanzania } \\
\text { [98] }\end{array}$ & $\begin{array}{l}\text { 'For admission' } \\
\text { Tanzania [31] }\end{array}$ & $\begin{array}{l}\text { 'For admission } \\
\text { Tanzania }[47,31]\end{array}$ & \\
\hline & & & & & $\begin{array}{l}\text { 'For specialized } \\
\text { care' Uganda[99] }\end{array}$ & $\begin{array}{l}\text { 'For surgery' Tanzania } \\
{[47]}\end{array}$ & \\
\hline & & & & & & $\begin{array}{l}\text { 'For blood transfusion' } \\
\text { Tanzania[23] }\end{array}$ & \\
\hline
\end{tabular}

Note: Papers providing a rich description of attracting factors are marked in bold; findings from methods involving open-ended questions are underlined. 
Table 5 Matrix of factors reported by papers to attract care seekers to different provider types: Supplies and services seen as good or recommended

\begin{tabular}{|c|c|c|c|c|c|c|c|}
\hline Provider type & $\begin{array}{l}\text { Community health } \\
\text { workers } \\
(n=3)\end{array}$ & $\begin{array}{l}\text { Drug shop/pharmacy } \\
(n=10)\end{array}$ & $\begin{array}{l}\text { Traditional } \\
\text { healer } \\
(n=1)\end{array}$ & $\begin{array}{l}\text { Private health } \\
\text { centre/facility } \\
(n=8)\end{array}$ & $\begin{array}{l}\text { Public health centre/ } \\
\text { facility } \\
\text { ( } n=13)\end{array}$ & $\begin{array}{l}\text { Hospital } \\
(n=11)\end{array}$ & $\begin{array}{l}\text { Provider type not } \\
\text { specified } \\
(n=10)\end{array}$ \\
\hline \multicolumn{8}{|l|}{ Attracting factor } \\
\hline \multirow[t]{5}{*}{$\begin{array}{l}\text { Provider supplies } \\
\text { (mostly drugs) and } \\
\text { facilities are good ( } n= \\
\text { 28) }\end{array}$} & $\begin{array}{l}\text { 'Drug availability' Ethiopia } \\
\text { [95] }\end{array}$ & Tanzania [91] & & $\begin{array}{l}\text { 'Drug availability' } \\
\text { Kenya[35] } \\
\text { Ethiopia[13] }\end{array}$ & $\begin{array}{l}\text { 'Drug availability' } \\
\text { Zambia[60]Uganda [102] }\end{array}$ & $\begin{array}{l}\text { 'Drug availability' } \\
\text { Zambia[93,78] } \\
\frac{\text { Uganda }}{[25]}[41], \text { Nigeria }\end{array}$ & $\begin{array}{l}\text { 'Availability of drugs' } \\
\text { Nigeria [20,48]Uganda[46], } \\
\text { Ghana[21] }\end{array}$ \\
\hline & $\frac{\text { 'Staff availability' Nigeria \& }}{\text { Ghana \& Uganda \& Kenya }}$ & $\begin{array}{l}\text { 'Drug availability' Nigeria } \\
{[28,26] \text { Tanzania[53,101] }} \\
\text { Uganda [32], [102,18] Ethiopia } \\
{[13]}\end{array}$ & & & $\begin{array}{l}\text { 'Well equipped' Kenya } \\
{[49,38] \text { Tanzania }} \\
\text { Uganda [16] }\end{array}$ & $\begin{array}{l}\text { 'Drips available' } \\
\text { Tanzania[101] }\end{array}$ & \\
\hline & & $\begin{array}{l}\text { 'Wide range of drugs' } \\
\text { Tanzania[101] } \\
\text { Malawi[24] }\end{array}$ & & & $\begin{array}{l}\text { 'Ward for in-patients' } \\
\text { Tanzania [47] }\end{array}$ & $\begin{array}{l}\text { 'Diagnostic facilities' } \\
\text { Zambia[93] } \\
\text { Tanzania[101] }\end{array}$ & \\
\hline & & & & & $\begin{array}{l}\text { 'Presence of laboratory' } \\
\text { Tanzania [47] }\end{array}$ & $\begin{array}{l}\text { 'Staff availability' } \\
\text { Zambia[93] }\end{array}$ & \\
\hline & & & & & 'Medical staff' Kenya [38] & & \\
\hline \multirow[t]{2}{*}{$\begin{array}{l}\text { Better 'quality of } \\
\text { services' (as a general } \\
\text { statement) ( } n=15)\end{array}$} & & $\underline{\text { Uganda[18] }}$ & Uganda[32] & $\begin{array}{l}\text { Kenya[14], } \\
\text { Ethiopia[10], } \\
\text { Uganda[41], } \\
\text { Ghana }[21]\end{array}$ & Ethiopia [39] Nigeria [62] & $\frac{\text { Uganda[41], Nigeria }}{[62]}$ & $\begin{array}{l}\text { Kenya[50,49], Tanzania [47], } \\
\text { Nigeria }[20,48], \\
\text { Mozambique[51], Ghana } \\
21]\end{array}$ \\
\hline & & & & & $\begin{array}{l}\text { 'Have better quality } \\
\text { control and regulation } \\
\text { of services' Nigeria [66] }\end{array}$ & & \\
\hline $\begin{array}{l}\text { Provider recommended } \\
\text { by another provider ( } n \\
=11 \text { ) }\end{array}$ & & & & Tanzania $[91,83]$ & $\underline{\text { Uganda }}[12,103,17]$ & $\begin{array}{l}\text { Tanzania } \\
{[69,104,34,75]} \\
\text { Uganda [103], }\end{array}$ & $\begin{array}{l}\text { 'Health facilities ' Tanzania } \\
\text { [105] } \\
\text { Burkina Faso[33] }\end{array}$ \\
\hline
\end{tabular}

Note: Papers providing a rich description of attracting factors are marked in bold; findings from methods involving open-ended questions are underlined 
give adequate and appropriate treatment that would cure their illnesses.

Positive attitudes by provider, including being friendly, polite, providing consolation and showing concern were important across all provider types. Health seekers were reported to desire the provision of health services with dignity, respect, and humility on the part of the provider. Many of the studies in this category used open-ended questions, a method classified as stronger evidence, although the absolute numbers were few. Several described important attitudes in health worker in terms of being friendly to patients [28,94], offering counselling and consolation $[18,34]$ and being caring in general $[12,70]$.

\section{Attracting factors to higher-level providers}

Specific attractions to higher-level providers were the qualifications of staff, perceived better 'quality of services', and recommendations to attend from another provider.

Higher-level facilities were frequently reported to be attractive due to the perceived higher level of formal training and experience of providers. Patients were reported to perceive these providers as competent, with greater expertise than others, and best suited to treat symptoms associated with uncomplicated malaria.

Private health clinics/health centres, public health facilities and hospitals were reported to be visited for their better 'quality of services'. Unfortunately, in many cases, this phrase was used without further explanation or deconstruction, possibly reflecting the nature of the studies, which used closed-question methods. However, in some cases, the term 'quality of services' was explained to include laboratory services, availability of drugs and qualified personnel. Others referred it as prompt diagnosis, appropriate treatment and good follow-up advice [48].

Other factors attracting people to providers included following recommendations from another provider. Such recommendations or referral, were described in cases where the initial provider was unable to treat the illness, when they would recommend another provider who was believed to be able treat that illness, or in cases when the provider recommended a facility where investigations or more complicated procedures such as blood transfusions could be carried out.

\section{Attracting factors to lower-level providers}

Specific factors reported to attract patients to lowerlevel providers were the timeliness of services, including convenience of opening hours and short waiting times, and the ability to have choice over what medicines to purchase.

Timeliness was reported as crucial in clients' choice of providers, and lower-level providers were therefore attractive because they operate for longer hours as well as at weekends, unlike public health facilities. They were also reported to be popular for the shorter waiting times. Patients were reported to appreciate that such timely services were possible because of the profit motive of drug shops and pharmacies.

Choice over medicines was only reported by a few studies, which mentioned that patients are satisfied by the ability to purchase specific desired medicines and in the quantities or dosages that they were able to afford or wished to purchase at that time.

\section{Changes in attracting factors and provider types reported over time}

The majority ( $\mathrm{n}=77,79 \%$ ) of papers eligible for inclusion in this review were published between the year 2000 and 2009, with only 10 papers published before this point, including just one since 1980 [49]. No strong trends in the types of attracting factors presented by papers from different years were identified, with most factors being mentioned by papers before and after the year 2000. However, it was noted that 'beliefs a provider can cure an illness', 'proximity or easy access' and 'timeliness of services' were factors reported slightly more frequently, proportional to the number of papers included in that time period, before the year 2000. Conversely, reports of the importance of 'specialist services' as attracting patients to providers emerged only after the year 2000, when reports of 'provider supplies and facilities' were also slightly more common amongst included publications.

Papers from across the years included all provider types, although papers with a focus on drug shops and community health workers were more common since the year 2000 .

\section{Discussion}

This review brings together papers that describe attributes of providers reported to attract patients to seek their health care services, specifically for malaria in Africa. An increasing number of papers have been published since the year 2000 that address this topic. The findings of this review add to those that have focused on attributes of patients and their communities, such as education level and socio-economic status, when trying to understand factors affecting access to health care. The review identified that several categories of factors that were reported to attract patients to providers were relevant across different provider types and different study settings: low cost of services, proximity of treatment source to the patient, a belief that the provider or their medicines could cure the illness and positive manner of the provider. Additional categories of factors were noted to attract patients to either higher- or lower-level providers: specific attractions to higher-level providers were 
the qualifications of staff, perceived better 'quality of services', and recommendations to attend from another provider; specific factors reported to attract patients to lower-level providers were the timeliness of services, including convenience of opening hours and short waiting times, and the ability to have choice over what medicines to purchase. Each of the factors identified can be considered in the design of interventions to increase access to health care for malaria in African settings.

This review focused on providers offering care in cases of malaria. The findings echo those found in studies and reviews of factors attracting patients to providers for other health services, such as for maternal health care and other childhood illnesses. Similar categories can be identified amongst papers describing provider attributes that attracted patients for other health services, including costs, proximity, timeliness and supplies [106-116], and the importance of health worker personalities and relationships with patients were even more prominently cited $[62,107,109,111,113,116-118]$. The findings presented in this paper were drawn from 14 different countries across Africa, without stark differences by country, suggesting some generalization of findings. However, the papers reflect the countries from which much malaria research emanates, with no contributions found from Central Africa, for example, which limits generalization. The increase in numbers of papers since the year 2000 is notable, although the review also identified that many factors identified in earlier papers were replicated in later publications, with the exception of more emphasis in later papers on specialist services and supplies. This could reflect changes in qualities desired in providers or a change to the framing of the research questions by investigators, perhaps suggesting a trend towards understanding the role of commodities in health care.

A limitation of the interpretation of the review's findings as identifying those factors most important to patients is the methodology used in the individual studies. Many of the studies were surveys, in which potentially important factors are pre-defined. The studies that used more open-ended methodologies tended to echo some of the same findings as the closed-question surveys but they also picked up other issues, including the importance of a belief that a particular provider could cure an illness and of the nature of the provider's interactions with patients. This points to the need for studies to continue to take open-ended approaches, in order to allow unanticipated issues to emerge. It also suggests that the list of factors attracting patients to providers may not be exhaustive, and indeed may appear skewed towards certain factors because of the questions asked. In addition, it was hard to interpret some of the broader factors listed but not deconstructed by authors, such as 'quality', 'costs' and 'access.' Such concepts tend to be composed of several notions, and carry different meanings for different individuals and groups. The more in-depth studies provided more insights for the research question by untangling these concepts rather than assuming a shared meaning by participants, researchers and readers.

While the review did find 97 papers mentioning provider characteristics affecting patient choice, these were often mentioned secondarily to individual patient or community factors. Rich descriptions of provider characteristics that attracted patients were relatively few. This may reflect the dominance of the discourse in public health currently that conceptualizes the responsibility for health at the individual level, with interventions targeted at empowering individuals to do 'the right thing' through provision of education and removal of financial and cultural barriers [119]. In global health, this can be seen to have arisen as part of the rapid reversal of the priorities set out in the comprehensive primary health care approach taken in the Alma Ata Declaration of 1978. When this horizontal strategy was superseded by more targeted, vertical programmes that were argued to achieve greater gains more quickly [120], conceptualizations of local populations shifted from active partners of demand-driven services to passive recipients of supplydriven services [121]. The concept of access can be seen as coupled with the top-down delivery of services, exemplified by initiatives to increase access to medicines, immunizations, sanitation and other health commodities. The Millennium Development Goals (MDGs) crystallized this targeted approach to meeting population needs for health care, and the rhetoric to 'increase access' can be found in the detail of all of the health-related MDGs [122].

Learning lessons from the literature on factors attracting patients to providers should include a reflection by policy makers and programme implementers about the assumptions made in the provision of services. Are patients expected to be responsible 'citizens', eager to seek care at 'appropriate' health facilities, as long as they have been educated and empowered financially? Or should patients be considered as agents, weighing up multiple desires and constraints, including the appeal of one provider over another? This literature review suggests that traditional barriers such as cost and proximity are important in access to health care. However, it also suggests that health services may increase their appeal if they were more responsive to client demands in terms of friendliness, timeliness, compassion and effectiveness. Multidimensional frameworks of health care access have described it as a degree of 'fit' between health care systems and individuals, households and communities [123]. This paper suggests that health services be proactive in developing their characteristics in line with patient preferences in order to evolve a good 'fit' with 
patient if they intend to improve health outcomes through access.

\section{Conclusions}

Concerns over how to improve access to health services have tended to focus on characteristics of patients and their communities. This paper has reviewed characteristics about providers that attract patients to attend. Several characteristics are presented that were reported to attract patients to providers of all types, including lower cost of services, close proximity to patients, positive manner of providers, medicines that patients believe will cure them, and timeliness of services. The paper argues that improving access to services requires attention to those factors that will attract patients, and recommends that public services are improved in the specific aspects identified in this review. The paper also argues that research should expand its lens to understand provider characteristics more carefully, especially using methods that enable open responses. Access must be reconceptualized beyond the notion of barriers to consider attributes of attraction if patients are to receive quality care quickly.

\section{Acknowledgements}

The authors are funded by the ACT Consortium through a grant to the London School of Hygiene \& Tropical Medicine from the Bill and Melinda Gates Foundation.

\section{Author details}

'Uganda Malaria Surveillance Project, Infectious Diseases Research Collaboration, Kampala, Uganda. ${ }^{2}$ Department of Clinical Research, London School of Hygiene and Tropical Medicine, London, UK. ${ }^{3}$ Department of Global Health \& Development, London School of Hygiene and Tropical Medicine, London, UK.

\section{Authors' contributions}

The review was conceived and designed by CIRC and SGS, papers were retrieved and analysed by JK, MK and $\mathrm{CN}$, all authors contributed to drafting the manuscript and gave final approval of the version to be published.

\section{Competing interests}

The authors declare that they have no competing interests.

Received: 17 November 2011 Accepted: 23 February 2012

Published: 23 February 2012

\section{References}

1. Roll Back Malaria Partnership: Global Malaria Action Plan For a malaria-free world Geneva: World Health Organisation; 2008.

2. Obrist B, Iteba N, Lengeler C, Makemba A, Mshana C, Nathan R, Alba S, Dillip A, Hetzel MW, Mayumana I, Schulze A, Mshinda H: Access to health care in contexts of livelihood insecurity: a framework for analysis and action. PLoS Med 2007, 4:1584-1588.

3. Hausmann-Muela S, Ribera JM, Nyamongo IK: Health-seeking behaviour and the health system response London: London School of Hygiene \& Tropical Medicine; 2003, DCPP Working Paper No. 14.

4. Hetzel MW, Iteba N, Makemba A, Mshana C, Lengeler C, Obrist B, Schulze A, Nathan R, Dillip A, Alba S, Mayumana I, Khatib RA, Njau JD, Mshinda H: Understanding and improving access to prompt and effective malaria treatment and care in rural Tanzania: the ACCESS Programme. Malar J 2007, 6:83.
5. Rutherford ME, Mulholland K, Hill PC: How access to health care relates to under-five mortality in sub-Saharan Africa: systematic review. Trop Med Int Health 2010, 15:508-519.

6. Ricketts TC, Goldsmith L: Access in health services research: the battle of the frameworks. Nurs Outlook 2005, 53:274-280.

7. Littrell M, Gatakaa H, Evance I, Poyer S, Njogu J, Solomon T, Munroe E, Chapman S, Goodman C, Hanson K, Zinsou C, Akulayi L, Raharinjatovo J, Arogundade E, Buyungo P, Mpasela F, Adjibabi CB, Agbango JA, Ramarosandratana BF, Coker B, Rubahika D, Hamainza B, Shewchuk T, Chavasse D, O'Connell KA: Monitoring fever treatment behaviour and equitable access to effective medicines in the context of initiatives to improve ACT access: baseline results and implications for programming in six African countries. Malar J 2011, 10:327.

8. Williams HA, Jones CO: A critical review of behavioral issues related to malaria control in sub-Saharan Africa: what contributions have social scientists made? Soc Sci Med 2004, 59:501-523.

9. Maslove DM, Mnyusiwalla A, Mills EJ, McGowan J, Attaran A, Wilson K: Barriers to the effective treatment and prevention of malaria in Africa: A systematic review of qualitative studies. BMC Int Health Hum Rights 2009, 9:26.

10. Deressa W, Ali A, Hailemariam D: Malaria-related health-seeking behaviour and challenges for care providers in rural Ethiopia: implications for control. J Biosoc Sci 2008, 40:115-135.

11. Ndyomugyenyi R, Neema $S$, Magnussen P: The use of formal and informal services for antenatal care and malaria treatment in rural Uganda. Health Policy Plan 1998, 13:94-102.

12. Batega DW, Greer GJ, Plowman BA: Home-based management of fever strategy in Uganda: assessment of implementation and operation at the district and community levels Kampala, Uganda: BASICS II Project. Department of Sociology, Makerere University; 2004.

13. Deressa W, Ali A: Malaria-related perceptions and practices of women with children under the age of five years in rural Ethiopia. BMC Publ Health 2009, 9:259.

14. Amuyunzu-Nyamongo M, Nyamongo IK: Health seeking behaviour of mothers of under-five-year children in the slum communities of Nairobi, Kenya. Anthropol Med 2006, 13:25-40.

15. Hetzel MW, Obrist B, Lengeler C, Msechu JJ, Nathan R, Dillip A, Makemba AM, Mshana C, Schulze A, Mshinda H: Obstacles to prompt and effective malaria treatment lead to low community-coverage in two rural districts of Tanzania. BMC Public Health 2008, 8:317.

16. Rutebemberwa E, Pariyo G, Peterson S, Tomson G, Kallander K: Utilization of public or private health care providers by febrile children after user fee removal in Uganda. Malar J 2009, 8:45.

17. Mbonye AK, Neema S, Magnussen P: Treatment-seeking practices for malaria in pregnancy among rural women in Mukono District, Uganda. $J$ Biosocial Science 2006, 38:221-237.

18. Chandler Cl, Hall-Clifford R, Asaph T, Pascal M, Clarke S, Mbonye AK: Introducing malaria rapid diagnostic tests at registered drug shops in Uganda: limitations of diagnostic testing in the reality of diagnosis. Soc Sci Med 2011, 72:937-944.

19. Okeke TA, Okafor HU: Perception and treatment seeking behavior for malaria in rural Nigeria: implications for control. J Human Ecol 2008, 24:215-222.

20. Okeke TA, Okeibunor JC: Rural-urban differences in health-seeking for the treatment of childhood malaria in south-east Nigeria. Health Policy 2010, 95:62-68.

21. Asenso-Okyere WK, Dzator JA, Osei-Akoto I: The behaviour towards malaria care - a multinomial logit approach. Soc Indic Res 1996, 39:167-186.

22. Deressa W, Ali A, Enqusellassie F: Self-treatment of malaria in rural communities, Butajira, southern Ethiopia. Bull World Health Organ 2003, 81:261-268.

23. Mubyazi G, Massaga J, Kamugisha M, Mubyazi JN, Magogo GC, Mdira KY, Gesase S, Sukwa T: User charges in public health facilities in Tanzania: effect on revenues, quality of services and people's health-seeking behaviour for malaria illnesses in Korogwe district. Health Serv Manage Res 2006, 19:23-35.

24. Munthali A: Managing malaria in under-five children in a rural Malawian village. Nordic Journal of African Studies 2005, 14:127-146.

25. Uguru NP, Onwujekwe OE, Tasie NG, Uzochukwu BS, Ezeoke UE: Do consumers' preferences for improved provision of malaria treatment 
services differ by their socio-economic status and geographic location? A study in southeast Nigeria. BMC Public Health 2010, 10:7.

26. Falade CO, Ogundiran MO, Bolaji MO, Ajayi IO, Akinboye DO, Oladepo O, Adeniyi JD: The influence of cultural perception of causation, complications, and severity of childhood malaria on determinants of treatment and preventive pathways. Int Q Community Health Educ 2006, 24:347-363.

27. Idowu OA, Mafiana CF, Luwoye IJ, Adehanloye O: Perceptions and home management practices of malaria in some rural communities in Abeokuta, Nigeria. Travel Med Infect Dis 2008, 6:210-214.

28. Onwujekwe O, Ojukwu J, Uzochukwu B, Dike N, Ikeme A, Shu E: Where do people from different socio-economic groups receive diagnosis and treatment for presumptive malaria, in south-eastern Nigeria? Ann Trop Med Parasitol 2005, 99:473-481.

29. Tolhurst R, Amekudzi YP, Nyonator FK, Bertel Squire S, Theobald S: "He will ask why the child gets sick so often": the gendered dynamics of intrahousehold bargaining over healthcare for children with fever in the Volta Region of Ghana. Soc Sci Med 2008, 66:1106-1117.

30. Amin AA, Marsh V, Noor AM, Ochola SA, Snow RW: The use of formal and informal curative services in the management of paediatric fevers in four districts in Kenya. Trop Med Int Health 2003, 8:1143-1152.

31. Njau JD, Goodman C, Kachur SP, Palmer N, Khatib RA, Abdulla S, Mills A, Bloland P: Fever treatment and household wealth: the challenge posed for rolling out combination therapy for malaria. Trop Med Int Health 2006, 11:299-313.

32. Minnesota International Health Volunteers: Improving malaria case management in Ugandan communities: lessons from the field Washington: The CORE Group; 2004.

33. Beiersmann C, Sanou A, Wladarsch E, De Allegri M, Kouyate B, Muller O: Malaria in rural Burkina Faso: local illness concepts, patterns of traditional treatment and influence on health-seeking behaviour. Malar $\lrcorner$ 2007, 6:106.

34. Kamat VR: The Anthropology of Childhood Malaria in Tanzania. In Anthropology and Public Health Bridging differences in culture and society.. 2 edition. Edited by: Hahn RA, Inhorn MC. Oxford: Oxford University Press; 2009:

35. Nyamongo IK: Health care switching behaviour of malaria patients in a Kenyan rural community. Soc Sci Med 2002, 54:377-386.

36. Mota RE, Lara AM, Kunkwenzu ED, Lalloo DG: Health seeking behavior after fever onset in a malaria-endemic area of Malawi. Am J Trop Med Hyg 2009, 81:935-943.

37. Castillo-Riquelme M, McIntyre D, Barnes $K$ : Household burden of malaria in South Africa and Mozambique: is there a catastrophic impact? Trop Med Int Health 2008, 13:108-122.

38. Mwabu G, Ainsworth M, Nyamete A: Quality of medical care and choice of treatment in Kenya. J Hum Resour 1993, 28:838-862.

39. Deressa W, Chibsa S, Olana D: Treatment seeking for malaria patients in East Shewa Zone of Oromia, Ethiopia. Ethiop J Health Dev 2003, 17:9-16.

40. Clarke SE, Rowley J, Bogh C, Walraven GE, Lindsay SW: Home treatment of 'malaria' in children in rural Gambia is uncommon. Trop Med Int Health 2003, 8:884-894.

41. Lindblade KA, O'Neill DB, Mathanga DP, Katungu J, Wilson ML: Treatment for clinical malaria is sought promptly during an epidemic in a highland region of Uganda. Trop Med Int Health 2000, 5:865-875.

42. Abdu Z, Mohammed Z, Bashier I, Eriksson B: The impact of user fee exemption on service utilization and treatment seeking behaviour: the case of malaria in Sudan. Int J Health Plann Manage 2004, 19:595-S106.

43. Nonvignon J, Aikins MK, Chinbuah MA, Abbey M, Gyapong M, Garshong BN, Fia S, Gyapong JO: Treatment choices for fevers in children under-five years in a rural Ghanaian district. Malar J 2010, 9:188.

44. Muela SH, Ribera JM, Tanner M: Fake malaria and hidden parasites - the ambiguity of malaria. Anthropol Med 1998, 5:43-62.

45. Tumwesigire $S$, Watson $S$ : Health seeking behavior by families of children suspected to have malaria in Kabale: Uganda. Afr Health Sci 2002, 2:94-98.

46. Amuge B, Wabwire-Mangen F, Puta C, Pariyo GW, Bakyaita N, Staedke S, Kamya M, Olico O: Health-seeking behavior for malaria among child and adult headed households in Rakai district, Uganda. Afr Heal Sci 2004, 4:119-124.

47. Leonard KL: Doctor quality, roads and patient access to health care in rural Tanzania. LSHTM Health Policy Unit seminar 14th March 20082008.
48. Onwujekwe O, Chukwuogo O, Ezeoke U, Uzochukwu B, Eze S: Asking people directly about preferred health-seeking behaviour yields invalid response: an experiment in south-east Nigeria. J Publ Health 2011, 33:93-100.

49. Mwabu GM: Health care decisions at the household level: results of a rural health survey in Kenya. Soc Sci Med 1986, 22:315-319.

50. Chuma JM, Thiede M, Molyneux CS: Rethinking the economic costs of malaria at the household level: evidence from applying a new analytical framework in rural Kenya. Malar J 2006, 5:76.

51. Lindelow M: The utilisation of curative healthcare in Mozambique: Does income matter? J Afr Econ 2005, 14:435-482.

52. Yeneneh H, Gyorkos TW, Joseph L, Pickering J, Tedla S: Antimalarial drug utilization by women in Ethiopia - A knowledge-attitudes-practice study. Bull World Health Organ 1993, 71:763-772.

53. Alba S, Dillip A, Hetzel MW, Mayumana I, Mshana C, Makemba A, Alexander M, Obrist B, Schulze A, Kessy F, Mshinda H, Lengeler C: Improvements in access to malaria treatment in Tanzania following community, retail sector and health facility interventions - a user perspective. Malar J 2010, 9:163.

54. Rutebemberwa E, Kallander K, Tomson G, Peterson S, Pariyo G: Determinants of delay in care-seeking for febrile children in eastern Uganda. Trop Med Int Health 2009, 14:472-479.

55. Ajayi IO, Browne EN, Garshong B, Bateganya F, Yusuf B, Agyei-Baffour P, Doamekpor L, Balyeku A, Munguti K, Cousens S, Pagnoni F: Feasibility and acceptability of artemisinin-based combination therapy for the home management of malaria in four African sites. Malar J 2008, 7:6.

56. Onwujekwe O, Dike N, Ojukwu J, Uzochukwu B, Ezumah N, Shu E, Okonkwo P: Consumers stated and revealed preferences for community health workers and other strategies for the provision of timely and appropriate treatment of malaria in southeast Nigeria. Malar J 2006, 5:117.

57. Ajayi IO, Falade CO, Olley BO, Yusuf B, Gbotosho S, Iyiola T, Olaniyan O, Happi C, Munguti K, Pagnoni F: A qualitative study of the feasibility and community perception on the effectiveness of artemether-lumefantrine use in the context of home management of malaria in south-west Nigeria. BMC Health Serv Res 2008, 8:119.

58. Onwujekwe O, Uzochukwu B, Eze S, Obikeze E, Okoli C, Ochonma O: Improving equity in malaria treatment: Relationship of socio-economic status with health seeking as well as with perceptions of ease of using the services of different providers for the treatment of malaria in Nigeria. Malar J 2008, 7:5.

59. Chibwana Al, Mathanga DP, Chinkhumba J, Campbell CH Jr: Socio-cultural predictors of health-seeking behaviour for febrile under-five children in Mwanza-Neno district Malawi. Malar J 2009, 8:219.

60. Baume C, Helitzer D, Kachur SP: Patterns of care for childhood malaria in Zambia. Soc Sci Med 2000, 51:1491-1503.

61. Muller $\mathrm{O}$, Traore $\mathrm{C}$, Becher $\mathrm{H}$, Kouyate B: Malaria morbidity, treatmentseeking behaviour, and mortality in a cohort of young children in rural Burkina Faso. Trop Med Int Health 2003, 8:290-296.

62. Onwujekwe O: Inequities in healthcare seeking in the treatment of communicable endemic diseases in Southeast Nigeria. Soc Sci Med 2005, 61:455-463.

63. Munguti K: Community perceptions and treatment seeking for malaria in Baringo district, Kenya: Implications for disease control. East Afr Med J 1998, 75:687-691.

64. Malik EM, Hanafi K, Ali SH, Ahmed ES, Mohamed KA: Treatment-seeking behaviour for malaria in children under five years of age: implication for home management in rural areas with high seasonal transmission in Sudan. Malar J 2006, 5:60.

65. Dzator J, Asafu-Adjaye J: A study of malaria care provider choice in Ghana. Health Policy 2004, 69:389-401.

66. Onwujekwe O, Ojukwu J, Ezumah N, Uzochukwu B, Dike N, Soludo E: Socio-economic differences in preferences and willingness to pay for different providers of malaria treatment in southeast Nigeria. AmJTrop Med Hyg 2006, 75:421-429.

67. Mboera LEG, Kamugisha ML, Barongo V, Rumisha SF, Msangeni HA, Msangeni HA: M, FK AY: Community knowledge, perceptions and practices on malaria in Mpwapwa District, central Tanzania. Tanzan Health Res Bull 2004, 6:37-41. 
68. de Savigny D, Mayombana C, Mwageni E, Masanja H, Minhaj A, Mkilindi Y, Mbuya C, Kasale H, Reid G: Care-seeking patterns for fatal malaria in Tanzania. Malar J 2004, 3:27.

69. Makundi EA, Malebo HM, Mhame P, Kitua AY, Warsame M: Role of traditional healers in the management of severe malaria among children below five years of age: the case of Kilosa and Handeni Districts, Tanzania. Malar J 2006, 5:58

70. Nuwaha F: People's perception of malaria in Mbarara, Uganda. Trop Med Int Health 2002, 7:462-470.

71. Okeke TA, Okafor HU, Uzochukwu BSC: Traditional healers in Nigeria: Perception of cause, treatment and referral practices for severe malaria. J Biosoc Sci 2006, 38:491-500

72. Ahorlu CK, Koram KA, Ahorlu C, de Savigny D, Weiss MG: Community concepts of malaria-related illness with and without convulsions in southern Ghana. Malar J 2005, 4:47.

73. Pilkington $\mathrm{H}$, Mayombo J, Aubouy N, Deloron P: Malaria, from natural to supernatural: a qualitative study of mothers' reactions to fever (Dienga, Gabon). J Epidemiol Community Health 2004, 58:826-830.

74. Akogun $O B$, John KK: Illness-related practices for the management of childhood malaria among the Bwatiye people of north-eastern Nigeria. Malar J 2005, 4:13.

75. Makemba AM, Winch PJ, Makame VM, Mehl GL, Premji Z, Minjas JN, Shiff CJ: Treatment practices for degedege, a locally recognized febrile illness, and implications for strategies to decrease mortality from severe malaria in Bagamoyo District, Tanzania. Trop Med Int Health 1996, 1:305-313

76. Oberlander L, Elverdan B: Malaria in the United Republic of Tanzania: cultural considerations and health-seeking behaviour. Bull World Health Organ 2000, 78:1352-1357.

77. Kamat VR: Reconsidering the allure of the culturally distant in therapy seeking: A case study from coastal Tanzania. Med Anthropol 2008, 27:106-135.

78. Williams HA, Kachur SP, Nalwamba NC, Hightower A, Simoonga C, Mphande PC: A community perspective on the efficacy of malaria treatment options for children in Lundazi District, Zambia. Trop Med Int Health 1999, 4:641-652

79. Warsame M, Kimbute O, Machinda Z, Ruddy P, Melkisedick M, Peto T, Ribeiro I, Kitua A, Tomson G, Gomes M: Recognition, perceptions and treatment practices for severe malaria in rural Tanzania: implications for accessing rectal artesunate as a pre-referral. PLOS One 2007, 2:e149.

80. Ribera JM, Hausmann-Muela S: The straw that breaks the camel's back Redirecting health-seeking behavior studies on malaria and vulnerability. Med Anthropol Q 2011, 25:103-121.

81. Salako LA, Brieger WR, Afolabi BM, Umeh RE, Agomo PU, Asa S, Adeneye AK, Nwankwo BO, Akinlade CO: Treatment of childhood fevers and other illnesses in three rural Nigerian communities. J Trop Pediatr 2001, 47:230-238.

82. Ahorlu CK, Dunyo SK, Afari EA, Koram KA, Nkrumah FK: Malaria-related beliefs and behaviour in southern Ghana: implications for treatment, prevention and control. Trop Med Int Health 1997, 2:488-499.

83. Simba DO, Kakoko DC, Warsame M, Premji Z, Gomes MF, Tomson G, Johansson E: Understanding caretakers' dilemma in deciding whether or not to adhere with referral advice after pre-referral treatment with rectal artesunate. Malar J 2010, 9:123.

84. Kamat VR: "I thought it was only ordinary fever!" cultural knowledge and the micropolitics of therapy seeking for childhood febrile illness in Tanzania. Soc Sci Med 2006, 62:2945-2959

85. Iwelunmor J, Idris O, Adelakun A, Airhihenbuwa CO: Child malaria treatment decisions by mothers of children less than five years of age attending an outpatient clinic in south-west Nigeria: an application of the PEN-3 cultural model. Malar J 2010, 9:354.

86. Uzochukwu BSC, Onwujekwe EO, Onoka CA, Ughasoro MD: Rural-urban Differences in Maternal Responses to Childhood Fever in South East Nigeria. Plos One 2008, 3(3):e1788.

87. Paulander J, Olsson H, Lemma H, Getachew A, San Sebastian M: Knowledge, attitudes and practice about malaria in rural Tigray, Ethiopia. Glob Health Action 2009, 2:1-7.

88. Kamat VR: Dying under the bird's shadow: Narrative representations of Degedege and child survival among the Zaramo of Tanzania. Med Anthropol Q 2008, 22:67-93.
89. Bukirwa H, Nayiga S, Lubanga R, Mwebaza N, Chandler C, Hopkins H, Talisuna AO, Staedke SG: Pharmacovigilance of antimalarial treatment in Uganda: community perceptions and suggestions for reporting adverse events. Trop Med Int Health 2008, 13(9):1-10.

90. Wiseman V, Scott A, Conteh L, McElroy B, Stevens W: Determinants of provider choice for malaria treatment: Experiences from The Gambia. Soc Sci Med 2008, 67:487-496.

91. Dillip A, Hetzel MW, Gosoniu D, Kessy F, Lengeler C, Mayumana I, Mshana C, Mshinda H, Schulze A, Makemba A, et al: Socio-cultural factors explaining timely and appropriate use of health facilities for degedege in south-eastern Tanzania. Malar J 2009, 8:144.

92. Mugisha F, Bocar K, Dong H, Chepng'eno G, Sauerborn R: The two faces of enhancing utilization of health-care services: determinants of patient initiation and retention in rural Burkina Faso. Bull World Health Organ 2004, 82:572-579.

93. Hanson K, McPake B, Nakamba P, Archard L: Preferences for hospital quality in Zambia: results from a discrete choice experiment. Health Econ 2005, 14:687-701.

94. Tolhurst R, Nyonator FK: Looking within the household: gender roles and responses to malaria in Ghana. Trans $R$ Soc Trop Med Hyg 2006, 100:321-326.

95. Deressa W, Ali A, Berhane Y: Maternal responses to childhood febrile illnesses in an area of seasonal malaria transmission in rural Ethiopia. Acta Trop 2007, 102:1-9.

96. Kamat VR, Nyato DJ: Community response to artemisinin-based combination therapy for childhood malaria: a case study from Dar es Salaam, Tanzania. Malar J 2010, 9:61.

97. Tarimo DS, Lwihula GK, Minjas JN, Bygbjerg IC: Mothers' perceptions and knowledge on childhood malaria in the holendemic Kibaha district, Tanzania: implications for malaria control and the IMCl strategy. Trop Med Int Health 2000, 5:179-184.

98. Foster D, Vilendrer S: Two treatments, one disease: childhood malaria management in Tanga, Tanzania. Malar J 2009, 8:240.

99. Mbonye AK, Bygbjerg IC, Magnussen P: Prevention and treatment practices and implications for malaria control in Mukono District Uganda. J Biosoc Sci 2008, 40:283-296.

100. Opiyo P, Mukabana WR, Kiche I, Mathenge E, Killeen GF, Fillinger U: An exploratory study of community factors relevant for participatory malaria control on Rusinga Island, western Kenya. Malar J 2007, 6:48.

101. Muela SH, Ribera JM, Mushi AK, Tanner M: Medical syncretism with reference to malaria in a Tanzanian community. Soc Sci Med 2002, 55:403-413.

102. Nshakira N, Kristensen M, Ssali F, Whyte SR: Appropriate treatment of malaria? Use of antimalarial drugs for children's fevers in district medical units, drug shops and homes in eastern Uganda. Trop Med Int Health 2002, 7:309-316.

103. Kallander K, Tomson G, Nsungwa-Sabiiti J, Senyonjo Y, Pariyo G, Peterson S: Community referral in home management of malaria in western Uganda: a case series study. BMC Int Health Hum Rights 2006, 6:2.

104. Montgomery CM, Mwengee W, Kong'ong'o M, Pool R: 'To help them is to educate them': power and pedagogy in the prevention and treatment of malaria in Tanzania. Trop Med Int Health 2006, 11:1661-1669.

105. Simba DO, Warsame M, Kimbute O, Kakoko D, Petzold M, Tomson G, Premji Z, Gomes M: Factors influencing adherence to referral advice following pre-referral treatment with artesunate suppositories in children in rural Tanzania. Trop Med Int Health 2009, 14:775-783.

106. Geissler PW, Nokes K, Prince RJ, Odhiambo RA, Aagaard-Hansen J, Ouma JH: Children and medicines: self-treatment of common illnesses among Luo schoolchildren in western Kenya. Soc Sci Med 2000, 50:1771-1783.

107. Adome RO, Whyte SR, Hardon A: Popular Pills: Community Drug Use in Uganda Amsterdam: Het Spinhuis; 1996

108. Abel-Smith B, Rawal P: Can the poor afford 'free' health services? A case study of Tanzania. Health Policy Plan 1992, 7:329-341.

109. Haddad S, Fournier P, Machouf N, Yatara F: What does quality mean to lay people? Community perceptions of primary health care services in Guinea. Soc Sci Med 1998, 47:381-394.

110. Muela SH, Mushi AK, Ribera JM: The paradox of the cost and affordability of traditional and government health services in Tanzania. Health Policy Plan 2000, 15:296-302. 
111. van der Geest S: Self-care and the informal sale of drugs in south Cameroon. Soc Sci Med 1987, 25:293-305.

112. Gauthier B, Wane W: The quest for better price and quality of health care in Chad The World Bank; 2008, Policy Research Working Paper 4462.

113. Mwabu G, Ainsworth M, Nyamete A: Quality of medical care and choice of medical treatment in Kenya: an empirical analysis. J Hum Resour 2001, 28:838-862.

114. Kloos H: Utilization of selected hospitals, health centres and health stations in central, southern and western Ethiopia. Soc Sci Med 1990, 31:101-114.

115. Odaga J: Health inequality in Uganda - the role of financial and non financial barriers. Policy Dev 2004, 2:192-208.

116. Gilson L, Alilio M, Heggenhougen $\mathrm{K}$ : Community satisfaction with primary health care services: an evaluation undertaken in the Morogoro region of Tanzania. Soc Sci Med 1994, 39:767-780.

117. D'Ambruoso L, Abbey M, Hussein J: Please understand when I cry out in pain: women's accounts of maternity services during labour and delivery in Ghana. BMC Publ Health 2005, 5:140.

118. Kiguli J, Ekirapa-Kiracho E, Okui O, Mutebi A, Macgregor H, Pariyo GW: Increasing access to quality health care for the poor: Community perceptions on quality care in Uganda. Patient Prefer Adherence 2009, 3:77-85.

119. Lupton D: The Imperative of Health London: SAGE Publications; 1995, Public health and the regulated body.

120. Walsh JA, Warren KS: Selective primary health care: an interim strategy for disease control in developing countries. N Engl J Med 1979, 301:967-974.

121. Rosato M, Laverack G, Grabman LH, Tripathy P, Nair N, Mwansambo C, Azad K, Morrison J, Bhutta Z, Perry H, Rifkin S, Costello A: Community participation: lessons for maternal, newborn, and child health. Lancet 2008, 372:962-971.

122. United Nations: Road map towards the implementation of the United Nations Millennium Declaration Report of the Secretary-General Geneva: United Nations General Assembly; 2001.

123. Mclntyre $D$, Thiede $M$, Birch $S$ : Access as a policy-relevant concept in lowand middle-income countries. Health Econ Policy Law 2009, 4:179-193.

doi:10.1186/PREACCEPT-2317562776368437

Cite this article as: Kizito et al:: Improving access to health care for malaria in Africa: a review of literature on what attracts patients. Malaria Journal 2012 11:55.

\section{Submit your next manuscript to BioMed Central and take full advantage of:}

- Convenient online submission

- Thorough peer review

- No space constraints or color figure charges

- Immediate publication on acceptance

- Inclusion in PubMed, CAS, Scopus and Google Scholar

- Research which is freely available for redistribution

Submit your manuscript at www.biomedcentral.com/submit 